\begin{tabular}{|l|l|l|}
\hline \multicolumn{2}{|c|}{ PublisherInfo } \\
\hline \hline PublisherName & $:$ & BioMed Central \\
\hline \hline PublisherLocation & $:$ & London \\
\hline \hline PublisherImprintName & $:$ & BioMed Central \\
\hline \hline
\end{tabular}

\title{
Unintended inhalation of nitric oxide by contamination of compressed air
}

\begin{tabular}{|l|l|l||}
\hline \multicolumn{2}{|c||}{ ArticleInfo } \\
\hline \hline ArticleID & $:$ & 4163 \\
\hline \hline ArticleDOI & $:$ & $10.1186 /$ ccf-1999-2221 \\
\hline \hline ArticleCitationID & $:$ & 2221 \\
\hline \hline ArticleSequenceNumber & $:$ & 22 \\
\hline \hline ArticleCategory & $:$ & Paper Report \\
\hline ArticleFirstPage & $:$ & 1 \\
\hline \hline ArticleLastPage & $:$ & 3 \\
\hline \hline & $:$ & RegistrationDate : 1999-11-16 \\
ArticleHistory & $:$ & OnlineDate $1999-11-16$ \\
\hline \hline ArticleCopyright & $:$ & Current Science Ltd1999 \\
\hline \hline ArticleGrants & $:$ & \\
\hline \hline ArticleContext & $:$ & 1305422 \\
\hline \hline
\end{tabular}




\section{Keywords}

Acute respiratory distress syndrome, air pollution, mechanical ventilation

\section{Comments}

This paper is of great interest to anyone involved in studying the effects of NO. The important findings are that the hospital supply reached $1270 \mathrm{ppb}$ of NO (higher readings have been found in more industrialised cities) and also that there seemed to be a therapeutic benefit to inhaling hospital air. The clinical relevance of the study is less clear as most patients receiving NO will have such severe lung injury that a high $\mathrm{FiO}_{2}$ is required.

\section{Introduction}

Inhaled nitric oxide is a selective pulmonary vasodilator that improves arterial oxygen tension in acute lung injury (ALI) and acute respiratory distress syndrome (ARDS). Very low concentrations are effective (60 parts per billion [ppb]). Compressed air in hospitals contains a variable amount of nitric oxide (NO), as a result of air pollution, and this compressed air is added to oxygen to ventilate critically ill patients.

\section{Aims}

To determine whether contamination of compressed air by $\mathrm{NO}$ affects haemodynamics and gas exchange in patients with ALI and ARDS, and whether unintended NO inhalation interferes with the therapeutic use of inhaled NO.

\section{Methods}


During two periods, the hospital supply of compressed air was continually monitored for NO by chemiluminescence (allowing the detection of less than $10 \mathrm{ppb}$ ). Environmental NO was also measured at a distant site. The effect of this unintentional NO inhalation was studied in 15 patients with ALI during the working day, when NO levels were highest. In the first ten patients the source of compressed air was changed from the central supply to a gas tank containing air free of NO. Measurements were made before, $15 \mathrm{~min}$ after the change, and $15 \mathrm{~min}$ after the return to baseline. In the final five patients the effects of 5 ppm inhaled NO were evaluated when the ventilator was connected to the central gas supply and to the gas tank.

\section{Results}

NO levels in the hospital air supply varied from less than $10 \mathrm{ppb}$ to $1270 \mathrm{ppb}$. They were above 80 $\mathrm{ppb}$ for $40 \%$ of the time. Replacement of the hospital compressed air with tank compressed air decreased $\mathrm{PaO}_{2}$ by $10 \pm 5 \%$, and increased pulmonary vascular resistance (PVR) by $13 \pm 7 \%$. Adding 5 ppm NO to the hospital supply of air did not affect $\mathrm{PaO}_{2} / \mathrm{FiO}_{2}$ or PVR but adding 5 ppm to tank air increased $\mathrm{PaO}_{2} / \mathrm{FiO}_{2}$ by $16 \pm 11 \%$ and decreased PVR by $14 \pm 8 \%$.

\section{Discussion}

This study shows that unintended inhalation of $\mathrm{NO}$ in industrialised areas may alter the $\mathrm{PaO}_{2}$ and may make the therapeutic use of NO less successful. Although NO is oxidised in air to nitric dioxide $\left(\mathrm{NO}_{2}\right)$ it is stable enough to persist for some time in compressed air. The NO levels observed were highest during working days, and were slightly less than the local enviromental pollution. The withdrawal of small amounts of $\mathrm{NO}$ in the hospital compressed air system produced measurable changes in $\mathrm{PaO}_{2}$. It is not thought that this could be due to methodology, as the air supply tubing was very rapidly swapped between supplies. Intentional inhalation of $5 \mathrm{ppm}$ of NO resulted in no improvements when added to hospital-supplied air, suggesting that patients who were going to respond to NO had already done so (to the small amount of enviromental contamination). NO is often used therapeutically when the patient is receiving high concentrations of oxygen and hence little unintentional NO. There may be implications for future prospective trials on NO as unintentional inhalation would have to be considered.

\section{References}

1. Benzing A, Loop T, Mols G, Geiger K: Unintended inhalation of nitric oxide by contamination of compressed air: physiologic effects and interference with intended nitric oxide inhalation in acute lung injury. Anesthesiology. 1999, 91: 945-950. 